\title{
ENGLISH TEACHING IMPLEMENTATION IN INDONESIAN PESANTRENS: TEACHERS' DEMOTIVATION FACTORS
}

\author{
Akhmad Habibi \\ email: akhmad.habibi@unja.ac.id \\ Muhammad Sofwan \\ email:muhammad.sofwan@unja.ac.id \\ Jambi University
}

\begin{abstract}
This qualitative inquiry is aimed at analysing demotivation factors of teachers in Indonesian Pesantrens (Islamic Boarding School) in implementing EFL teaching. The research is appropriately undertaken as a qualitative research with a case study approach. The research sites for this study are two Pesantrens in Jambi, one of Indonesian Provinces. Eight English teachers were involved as the participants to providebroader perspectives of the participants in relation to the EFL teaching. The researcher use three kinds of instruments in collecting the data; interview, focus group discussion, and document review. The researcher conducted the observation, interviewed the teachers, held focus group discussion, and collected related documents to support the data.To assess the trustworthiness of the research, the researcher did triangulation, member checking and reflexivity. The findings describe working condition (financial matter and working overload); curriculum (rapid changing of Indonesian curriculum and lack of teaching and supporting materials); facilities (classroom temperature and over-crowded classroom); students (lack of basic knowledge and lack of motivation).
\end{abstract}

Keywords: Indonesian, EFL Teacher, Implementation, and demotivation Factors

\section{INTRODUCTION}

Demotivation studies of teachers have been a thought provoking theme for educational researchers for years (Spear, Gould, \& Lee, 2000; Dinham \& Scott, 2000; Zhang, 2007; Addison \& Brundret, 2008; Kiziltepe, 2008). The previous studies mainly 
discussed that the demotivation factors which significantly contributed to the quality of education, teaching and learning process, and graduate quality were rigged on the area of students' lack motivation, limited sources of teaching and learning materials, insufficient salaries, big classes, and curriculum matters (Johnson, 2000). These studies are considered significantly useful for both the betterment of education system and evaluation to consider a new educational policy and/or regulation.

In the area of EFL (English as a Foreign Language), teachers demotivation factors also become one of popular research focuses (Johnson, 2000; Mukminin, Muazza, Hustarna, \& Sari, 2015; Tziava, 2003; Aydin, 2012; Lynche, 2008; Fattash, 2013; Hettiarachchi, 2013; Soureshjani \& Riahipour, 2012). Some of the studies show that the demotivating problems of Teachers of English are related to teaching profession, curriculum, working condition, students and their parents, colleagues and school administrators, and physical conditions (Aydin, 2012; Fattash 2013; Johnson, 2000).

Although there are plenty of studies in relation to the topic of English teachers' demotivation factors, there are a few research results published in context of Indonesian EFL. One of the few published results is research by Mukminin, Muazza, Hustarna, \& Sari (2015) which found that students' lack of proficiency in English and motivation, limited facilities, and overloaded classrooms are among the factors of English teachers' demotivation. They also offered policy recommendation in accordance with their findings; providing teaching media, providing satisfying language learning facilities, and facilitating Indonesian teachers of English with EFL trainings and seminars. With few published research on the topic, it is important that the continuity of the research on the similar topic.

The current study proposes the teachers' of English demotivation factors to enrich and broaden research horizons and sources in the context of Indonesian English teaching and learning process. Additionally, this study was conducted in Indonesian Pesantrens (Islamic Boarding School). Pesantrens in Indonesia have been significantly contributing to Education across the country since preIndonesian Independence time. As the oldest Indonesian education 
system, Pesantrens have historically implemented EFL as one of compulsory subjects in their curriculum (Habibi \& Sofwan, 2014). Thus, the research is purposed to deeply analyze and elaborate factors of teachers' of English demotivation in two Indonesian Pesantrens seen from the teachers' perspectives. Further, the research is hoped to significantly contribute to EFL development, Indonesian educational system, and Islamic education around the world.

\section{METHOD}

The research was appropriately undertaken as a qualitative researchwith a case study approach. Qualitative research is a kind of educational research in which the researcher focuses on the views of participants. The goal of conducting a qualitative study has historically been "to explore, explain, or describe the phenomenon of interest" and a case study is one of the qualitative traditions (Creswell, 2007; Patton, 1990). It is commonly used to understand people's experiences and to express their perspectives. Meanwhile, according to Johnson and Christensen (2008), a case study is a form of qualitative research that is focused on providing a detailed account of one or more cases.

This research utilized the qualitative method within a case study in order to describe or elaborate the research problems in relation to teachers' demotivation factors in Indonesian Pesantrens' EFL. The study utilized interview, focus group discussion (FGD), and document review as the instruments of data collection. The interview sessions were conducted for three weeks in December, 2015 with all the participants. The FGD sessions were held twice in two different places, FGD 1 in Pesantren Aljauharen and FGD 2 in Pesantren Ass'ad. The interview and FGD sessions were carried outin Bahasa Jambi to give the participant a free room to argue and opine and recorded with a smarthphone, Lenovo K4 Vibe note. Further, the documents were obtained by asking them from the administration staff working in the two Pesantrens and other resources.

The analysis of the data from the interview and FGD were transcribed, codified using an online qualitative application Atlas.ti, 
divided into themes and elaborated. The document data were reviewed to support all data from interview, FGD, and observation.

To establish the trustworthiness of the study or to verify the accuracy of the data, findings, and interpretations, several measures take to insure the trustworthiness of the data collected (Creswell 2007). Further, the trustworthiness of the research was assessed using triangulation, member checking, and self-reflection. Triangulation is a method used by qualitative researchers to check and establish validity in their studies by analyzing a research question from multiple perspectives (Patton, 1990).In addition to the triangulation, The researcher transcribed the interview excerpts. After transcribing the data, the researcher gave it back to the participants that have been interviewed to make sure what they said are right, as a system of checks of the data or member checking (Patton, 1990). In qualitative research, self-reflection is the attempt of researchers to explicitly identify their biases, values, and personal interest about their research topic, process, and access to the research participants (Creswell, 2007).

Sampling procedure of this research is both purposive. In purposive sampling, the reseacher specifies the characteristics of participants and then tries to locate individuals who have those characteristics (Creswell, 2007). Theories say that for qualitative research, the number of participants is not definite; they can be one or more (Creswell, 2007; Merriam, 1990). Patton (1990) stated that the participants in qualitative research are from 5 participants. The participants of the research were 8 English teachers (interview and FGD using) teaching in two Indonesian Pesantrens. In the research principle ethics, respect for persons requires a commitment to ensuring the autonomy of research participants where autonomy may be diminished and to protect people from exploitation of their vulnerability. The dignity of all research participants must be respected. Adherence to this principle ensures that people will not be used simply as a means to achieve research objectives (Mack, Woodsong, Macqueen, Guest, \& Name 2005). In this research, names of the participants are a pseudonym in order to keep the participants confidentially and make them feel well- being as the participants. 
Table 1.Research group participants

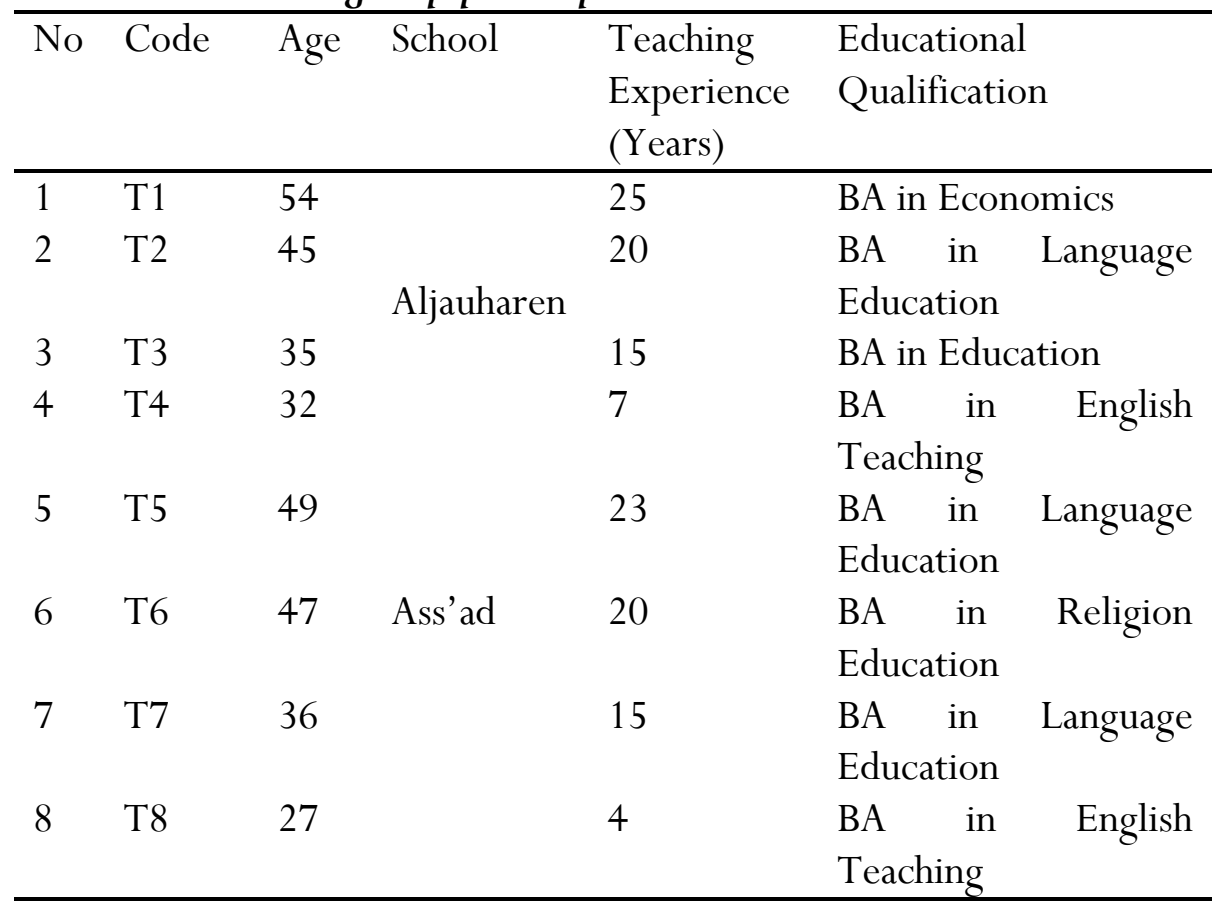

\section{FINDINGS}

The findings show working conditions, curriculum, and students and their parents are the demotivating factors in English teaching and learning in Pesantrens of Jambi, Indonesia. The main goal of this research was to investigate the demotivating factors among Indonesian Pesantrens'(Islamic Boarding Schools) teachers in teaching English as a foreign language at two Pesantrens in the city of Jambi, Indonesia. Due to the fact that every factor is implicated, it was difficult to jump to the conclusion of which factors have more significant impacts than other factors leading to the teachers' performance in Teaching English as a Foreign Language, demotivation factors. However, through Glaser and Strauss's (1967) in the constant comparative method, four important and implicated themes presented in this research were; 
English Teaching Implementation

\section{Table 2. Themes and subthemes}

\begin{tabular}{|c|c|c|}
\hline $\mathrm{No}$ & Theme & Subthemes \\
\hline 1 & Working Condition & $\begin{array}{l}\text { 1. Financial problems } \\
\text { 2. Teaching workload }\end{array}$ \\
\hline 2 & Curriculum & $\begin{array}{l}\text { 1. Rapid changing of curriculum } \\
\text { 2. Lack of teaching and supporting } \\
\text { materials }\end{array}$ \\
\hline 3 & Facilities & $\begin{array}{l}\text { 1. Classroom condition } \\
\text { 2. Overcrowded classroom }\end{array}$ \\
\hline 4 & $\begin{array}{l}\text { Students and their } \\
\text { parents }\end{array}$ & $\begin{array}{l}\text { 1. Lack of Students Motivation } \\
\text { 2. Students' Limited Knowledge of } \\
\text { English }\end{array}$ \\
\hline
\end{tabular}

\section{Working Condition}

The findings demonstrated that the subject encountered certain problems pertaining to the demotivation factors that are related to the working condition in Pesantrens. This factor is triggered by the monthly cash which the teachers bring to home monthly and teaching hours that they have to face weekly.

Six out of eight participants are not yet government employees and five of them have not been certified. They usually earn approximately $\$ 150 \mathrm{a}$ month, the stipend which is under the Jambi minimum monthly wages, $\$ 200$. These facts are revealed by almost all teachers in the interview session:

"Teaching is very dedicated job here in our school. We have to teach 5 days a week. However, we still have a matter of financial. I can't afford the bills with the salary I earn from the Pesantren, paying my children schools, electricity, running water, food, and other daily needs. The result is, I must work hard to fulfill the needs, Ngojek (driving a motorbike as a public transportation), doing fishing in Batanghari river, and other jobs which could support our life" (T3)

"One thing that the authority should really pay attention at is our payment. I am no civil servant. My salary is not sufficient to pay our bills. Such a pity thing to tell the truth but that is the truth. Many people say, if you want money, 
don't be a teacher. However I love being a teacher. Hoping every deed will be blessed by Allah, the Almighty God" (T6)

In the FGD session, all teachers almost agree on the payment that they earn from the institution is not sufficient for their daily need. Some teachers said that they have to do extra works to get more money to pay the bills:

"I think all agree on the financial matter that we face. It truly demotivates us to teach here in Pesantrens. We do hope that we will be given attention [from the authority]" (FGD 1)

"It is not all about the money but it is one of many factors demotivating us, teachers, in teaching. We have to do other jobs to pay our bills. As a consequence, we do not have full consents in doing our profession as teacher" (FGD 2)

However, teachers who are government employees do not have problems with the finance due to the more income they earn than contracted teachers get from Indonesian government, salary and other fringe benefits:

"The income we get from our boss [Indoensian government] is enough for us. It includes salary and other extra money. Furthermore, as certified one, I also get my certification money. It is a double salary" (T1)

The interview, FGD, and documentation data above indicated that one of the demotivating factors emerged for most teachers in Jambi Pesantrens is regular income. The teachers suggest that the government or related authorities pay more attention to the problems by giving more attention to solving the problems.

Beside the financial matters faced by the teachers, over workload is undeniably being one the major problems in teachers' teaching demotivation of English Language Teaching in Indonesian Pesantrens. There are 353 students with ten classes in Pesantren Aljauharen meaning there are 10 classes. In addition, there are more 
than 1000 students in Pesantren Assad with 33 classes. One of the programs of these two Pesantren requires their students to have Languages (Arabic and English) courses as parts of their program besides regular English subjects in line with Indonesian National Curriculum. This workload becomes one of the factors demotivating teachers of English to do their job, teaching English:

"I teach many classes. Here, in Ass'ad, there are more than a thousand students. We have to teach at night and in the morning as it is a part of the Pesantren programs. I believe it also becomes demotivation factors for us. Many things to do for our programs in Pesantrens".(T7)

"I think one of the problems in our Pesantren is the teaching workload. I teach more than 20 hours a week. Additionally, I have to do my extra works. It is such a tiring day for me though. However my dedication to teaching cannot be doubted". (FGD 1)

\section{Curriculum}

There are two main teachers' demotivating factors in regard to the curriculum implementation of English Language Teaching in these two Pesantrens. They are; the rapid changes of the curriculum and lack of teaching and supporting materials.

Indonesian Education curricula change rapidly. It is one of the problems in teaching situation of Indonesian Pesantrens. Indonesian Pesantrens commonly promote two kinds of curricula; National curriculum which is implemented in morning time and Religion curriculum at night time, including these two Pesantrens (Habibi \& Sofwan, 2016). The teachers in the FGD and interview sessions revealed:

"We can't follow the change of the Indonesian curricula. This year [2015], there are two changes; 2013 curriculum and KTSP (2004 curriculum). We are confused what the government actually want us, teachers do. We have to again and again read the regulation. in addition, the trainings on the newest curriculum is not sufficiently available" (FGD 2) 
“I personally don't have any idea. I have to keep updating with our ministry policy. In our duty as teachers we have to do what our boss orders including the curriculum implementation. And I am sometime demotivated because of the regulation" (T4)

The phenomenon of the rapid and dynamic curricula changes has directly affected negatively on the administration to providing teachers with teaching and other supporting materials in relation to the teaching and learning in English classes. It unfortunately also becomes one of teachers' demotivating factors in Jambi Pesantrens English Language Teaching:

"I don't have many supporting and teaching material in accordance with the latest curriculum that e implement in this school, too bad, sometime I feel a bit lazy to teach in the classroom. We need preparation in teaching. I am not a kind of a teacher who can teach without learning or teaching materials" (T6)

"Teaching and other supporting materials are still problems in our school. I think we all are in the same boat about this problem. I hope we can gain our ability to solve the problems by ourselves" (FGD 1)

\section{Facilities}

Another important issue demotivating Indonesian Pesantrens in teaching English as a foreign language at two Pesantrens in the City of Jambi was facilities including the weather in the classrooms. With more than thirty students in one classroom and with no coolers there, teachers found it difficult to transfer their knowledge to their students. Participants in this study informed in FGD and interview:

"I really feel hot in the classrooms. The hot classroom is always a major problem which I face every time I enter the rooms, especially when the sun shines in the middle of the day" (T8)

"The students feel the heat. With more than 40 students in a room; what could be expected. I really feel bad about the condition of the classrooms because there are no coolers. 
Should there be any coolers, they are not functional" (FGD

2)

Beside the classrooms' temperature, the overcrowded room is also the problem faced by both the teachers and students. An ideal language classroom should not have more than 30 students in the room. However, in these two Pesantrens, there are more than 40 students in one classroom. One of the participants revealed:

"The students are many in one room of the class. There are around 40 to 50 students in one room which is too crowded. We can't maximally manage to transfer information and knowledge. I hope there will be solution from the school side and other related stake holders" (T1)

\section{Students}

One of the classic and common themes in relation to the teachers' demotivation factors in education that also appeared from this current research interview and FGD data was students' limited basic knowledge of English language. All interviewees in this research informed that students' limited basic knowledge in English language was a major and everlasting problem demotivating the teachers to teach English as a foreign language in those two Pesantrens. Some of the teachers reflected in the interview sessions:

"The students make me feel a bit discouraged because of their basic knowledge of English. They did not pay attention to English. May be because they don't like it. This factor certainly demotivates me to teach English" (T5) "I have been teaching here for more than twenty years, never do I find students who have a good English as their basic knowledge. However, it is our responsibility to make them good in English" (T2)

Some of the teachers realize that their job is to make their students to be good in English language. In addition, the teachers also discussed the same idea from the LGD sessions as emerged from the interview sessions: 
"we believe that the limitation of the students' basic knowledge is among the factor demotivating us to teach in English classroom. However, we agree on our responsibility to make them able to speak English well in thier preparation to face global competition" (FGD 1)

The commitment of teachers to their profession was also put in doubt because of what was seen as students' lack of motivation to learn English in the language classes. These factors emerged in the interview and FGD sessions:

"I have ever asked my niece who apparently is one of the students in my school and she said that she does not like English because of many things. This answer is also a form of students lack motivation in English learning and certainly effects on the teachers' motivation to teach English" (T3) "We enter the classrooms with almost all of the students have low rate of motivation to learn English. It is maybe because we do not teach them in appropriate ways. I hope we are not demotivated, but we do. Engaging student with fun activities will be the problem solving. Our lacks of ability in making English to be fun to learn is the real holdbacks" (FGD 1)

Some of the teachers argue that the problem actually relies on their ability to make the students to be motivated in attending the English process of teaching and learning. However, they still feel demotivated because the students do not have enthusiasm in learning English in their classes.

\section{DISCUSSION}

From this study, it is revealed that Pesantrens teachers' demotivation factors are mostly in relation to the external factors which practically decrease teachers' motivation in teaching English to their students. The factors are working condition which includes the financial matter and working overload; curriculum which refers to rapid changing of curriculum and lack of teaching and supporting materials; facilities that are classroom temperature and over-crowded 
classroom, and students which have lack of basic knowledge and motivation.

Firstly, the findings demonstrated that the subject encountered certain problems pertaining to the demotivation factors that are related to the working condition in Pesantrens. This factor is triggered by the monthly cash which the teachers bring to home monthly and teaching hours that they have to face weekly. The fact that most teachers are contract employee becomes a salient factor influencing their income as teacher. Beside the financial matters faced by the teachers, work workload is undeniably being another major problem in teachers' performance English Language Teaching in Indonesian Pesantrens. There are many classes that they have to teach regularly in a week. Overwhelmingly, they also prepare all materials and lessons plan by themselves.

Secondly, Indonesian Education curricula change rapidly. It is one the problems in teaching situation of Indonesian Pesantrens. Indonesian Pesantrens commonly promote two kinds of curricula; National curriculum which is implemented in morning time and Religion curriculum at night time, including these two Pesantrens (Habibi \& Sofwan, 2016). Furthermore, the phenomenon of the rapid and dynamic curricula changes has directly affected negatively on the administration to providing teachers with teaching and other supporting materials in relation to the teaching and learning in English classes. It unfortunately also becomes one of teachers' demotivating factors in Jambi Pesantrens English Language Teaching.

Another important issue demotivating Indonesian Pesantrens in teaching English as a foreign language found at these two Pesantrens in the City of Jambi was facilities including the weather in the classrooms. With more than thirty students in one classroom and with no coolers in the rooms, teachers found it difficult to transfer their knowledge to the students.

The last factor revealed in this current study is the students. Two of the classic and common problems in teachers extrinsic factor demotivate teacher in teaching languages across the worlds are students' limited basic knowledge of the languages and lack of motivation in the activity. All interviewees in this research informed 
that students' limited basic knowledge and motivation were major problems in their classes influencing their mood and motivation in doing their job negatively.

There are plenty of research have explored and presented teachers demotivation factors in education in general and specifically in teaching English as a foreign language and revealed several theme findings and discussions such asstudents who are demotivated (Addison \& Brundrett, 2008; Aydin, 2012; Chambers, 1993; Fattash, 2013; Johnson,2000; Kiziltepe, 2008; Linares et al., 2009; Lynch, 2008; Mukminin, Muazza, Hustarna, \& Sari, 2015), overload of working (Addison, Brundrett, 2008;Aydin, 2012; Dinham \& Scott, 2000; Doyle \&Kim 1999; Spear et al., 2000), classrooms which are overcrowded(Lynch, 2008; Willows, 2011), salary (Doyle \& Kim 1999; Johnson, 2000; Spear et al., 2000; Tiziava, 2003), and facilities limitation (Aydin, 2012; Dinham \& Scott, 2000; Doyle \& Kim 1999; Hettiarachchi, 2013; Lynch,2008; Johnson, 2000; Mukminin, Muazza, Hustarna, \& Sari, 2015) However, there were no prior studies which have focused specifically on the demotivating factors among Pesantrens (Islamic Boarding School) teachers in teaching English as a foreign language. In addition, Pesantrens as the oldest educational institutions in Indonesia have long history in implementing the teaching of languages (Arabic and English) in their curriculum (Daulay, 2009)

\section{IMPLICATION AND POLICY RECOMMENDATION}

The goals of this current research are used to explore and present the demotivating factors among Indonesian Pesantrens teachers teaching English as a foreign language. We found four salient and implicated themes. They are working condition (financial matter and working overload); curriculum (rapid changing of Indonesian curriculum and lack of teaching and supporting materials); facilities (classroom temperature and over-crowded classroom);students(lack of basic knowledge and lack of motivation).

Policy recommendations and implications can be taken from the findings of this current research. The significance contribution from the authorities in relation to the teachers' income raise and providing more budgets to new teacher recruitment is significant to be 
considered. The availability of English teaching and supporting materials and the appropriate and established curriculum should also becoming priority attention of the Ministry of National Education. All stake holders are suggested to build more supporting facilities and limit the student number in one classroom so that the teaching and learning process can run appropriately. Teachers should have way out to boost student motivation and knowledge in the process with the support from educational trainings which hope to be held by all related authorities.

\section{REFERENCES}

Addison, R., \& Brundrett, M. (2008). Motivation and demotivation of teachers in primary schools: The challenge of change. Education, 36(1), 79-94.

Aydin, S. (2012). Factors causing demotivation in EFL teaching process: A case study. The Qualitative Report, 17 (101), 1-13.

Chambers, G. (1993). Taking the 'de' out of demotivation. Language Learning Journal, 7, 13-16.

Creswell, J, W. (2007). Qualitative inquiry and research design: Choosing among five traditions. Thousand Oaks, CA: Sage Publications.

Daulay, H. P. (2009).Dinamika pendidikan Islam di Asia Tenggara. Jakarta: Rineka Cipta.

Dinham, S. \& Scott, C. (2000). Moving into the third, outer domain of teacher satisfaction.Journal of Educational Administration, 38(4), 379-396.

Dörnyei, Z. (2001). Teaching and researching motivation. Essex: Pearson Education Limited.

Fattash, M. M. (2013). Demotivating factors of University ESL teachers. International Journal of Humanities and Social Science, 3(19), $125-132$.

Habibi, A., \& Sofwan, M. (2014). Problematika dunia pendidikan islam abad 21; tantangan pondok Pesantren Jambi. Jurnal khazanah Intelktual Balitbanda Prov. Jambi, 4(2) 12-22. 
Hettiarachchi, S. (2013).English language teacher motivation in Sri Lankan public schools.Journal of Language Teaching and Research, 4 (1), pp. 1-11.

Johnson, B., \& Christensen, L. B. (2008). Educational research: Quantitative, qualitative, and mixed approaches. Boston: Sage Publications.

Johnson, C. R. (2000). Factors influencing motivation and de-motivation of Mexican EFL teachers. Paper presented at the annual meeting of Teachers of English to Speakers of Other Languages, Vancouver, Canada.

Mack, N., Woodsong, C., M. MacQueen, K., M. Guest, G. \& Name, E. (2005). Qualitative Research Methods: A Data Collector's Field Guide. Family Health International. Research Triangle Park, NC, USA

Merriam, S. (1998).Qualitative research and case study applications in education. San Francisco, CA: Jossey Bass.

Patton, M. (1990).Qualitative evaluation and research methods. Beverly Hills, CA: Sage. 